\title{
The Use of Snowball Throwing in Teaching Reading at The Second Year Students of SMPN 8 Palopo
}

\author{
Wahidin \\ State Islamic Institute of Palopo (IAIN Palopo), South Sulawesi Indonesia \\ wahidin@iainpalopo.ac.id
}

\begin{abstract}
This thesis uses snowball to improve student reading with the research question, "How to use snowball throwing in SMPN's second-year students. This research employed Classroom Action Research (CAR) with cycles: first cycle, second cycle. Each cycle consists of four steps: planning. Acting, observing, reflecting. Four meetings during the research cycle. Class VIII, three samples of this study, consisted of 20 students. The study result revealed that Cycle 2 was better than Cycle one scores. During the lesson, the students showed great enthusiasm. Cycle 2's mean score is 82,75 , and the percentage of student activity observation The student reading mastery increases after Cycle 2 . The appropriate way to teach reading using snowball throwing is: (1) giving students more motivation to build confidence and spirit to study hard and be active in learning. (2) Before starting the learning process, more explanation of the material and giving the game than allowing the students to say what they do not understand. (3) Giving reward/gift for appreciation, (4) grouping students into a small group of 5 students. (5) Narrative text glossaries (6) Observers and writers were observing student activities. (7) Testing students to know the students ' improvement in reading after Using Snowball Throwing Learning (focus on the narrative text)
\end{abstract}

Keywords: Reading Narrative Text, Snowball Throwing, Teaching Reading Skills

\section{INTRODUCTION}

Reading is one of the communication acts that consist of communicative activity and becomes the center for concept-building and comprehension-stimulating thinking. By having excellent reading skills, people can understand English written text well. Therefore, students are supposed to have the reading skills; especially junior high school students will continue their studies in high school (Iksan \& Dirham, 2018). To teach students to read, a teacher often finds problems, such as finding the meaning of words in the text, difficulty explaining the purpose of the text, and difficulty explaining the text. Factors such as incapacity and low interest may account for some issues. Many teachers believe the problem is the inability to use instructional strategies or learning techniques that help students improve their readability.

Students ' interest in learning a second language is influenced by the lessons and how the classroom teaches them. So if a teacher wants to improve student language mastery, they must be aware of the feelings of the students and create a supportive learning atmosphere in the classroom. In lecturing, they should give opportunities and motivate students to read actively. If students are interested, they are motivated to read. High motivation to practice reading will improve comprehension of reading.

The problems in SMPN 8 Palopo were that the students rarely discussed and shared materials because the reading activity still depended on the teacher's explanation, e.g., 
the teacher explaining the materials in front of the class, and the students listened to her explanation. Some students were active, but others were passive. That happened because some students dared to ask and share views with teachers, but the other students did not. The students were still afraid to answer the teacher's questions and still shy about their teacher's views. When students pay serious attention, most of the reading process comprehends the message. This situation also occurs in most second-year students at SMPN 8 Palopo, who still face difficulty reading skills on the narrative text and always get bored when reading the text because they repeatedly read the text to understand the next. Just try to know the meaning of each word from the text to get the text's central idea. The students spent a long time understanding the next and do not have the same opportunity to understand the next. One difficulty students face is remembering what they have read. Most students still can not read well and hard to understand (Ilham, 2020).

They are many techniques that can be used to teach an understanding of reading. However, the writer applies a snowball throwing to teach students reading comprehension as an alternative way to create an active teaching-learning process. Snowball throwing technique is one kind of cooperative learning model in which students work in small groups, and each student is forced to be active in this teamwork format, and the students get the opportunity to interact. In this interaction, students enjoy learning. A narrative text is a text that focuses on specific participants. Its social function is to tell stories about past events and to entertain our stories with readers / hears. The purpose of the narrative, other than entertainment, can make the reader think about an issue and teach them a lesson. The language features used in the narrative text, according to Antonio Wardman, are the use of adjectives that form noun phrases using time connectives, the use of adverbs, the use of past tense, the use of saying verbs, and the use of specific characters (Iksan, n.d.). However, in this research, the writer focuses on using the past tense, using time-connective conjunctions, and using adverbs. It is a snowball throwing technique. Cooperative learning techniques are useful for teaching reading, where cooperative learning involves learning from each other in groups (Wadirman et al., 2008).

The writer chose snowball throwing as SMPN 8 Palopo 's second-year snowball throwing students will exchange information and discuss the text in reading. Snowball throwing makes students behave together towards the condition given by the teacher, and the students can go through any problem they face through working together awkward atmosphere. Snowball throwing also helps to solve the problem of classes that are too large to offer many opportunities to apply their reading comprehension, and they are more active in discussing their teacher's reading material, offering many advantages, creating and encouraging the individual's insight into their comparative strengths and weaknesses to generate and share the idea. According to Setiawan, the learning environment and management system of cooperative learning for snowball throwing offers opportunities for learning democracy, enhances students ' appreciation of academic learning, prepares students to learn about collaboration and social skills through the active participation of learners in small groups, offers learning opportunities. It builds a positive relationship between teacher, student, and student, and also creates a better chance to learn English more effectively (Setiawan, 2019).

Numbers of studies were conducted on this topic, Dwi Melinda Nebella Studied (2018) YouTube videos and snowball throwing technique to improve student speaking 
skills and found that using the snowball throwing technique is effective in improving student speaking skills. Nurbaya (2009) also studied the effect of using Snowball Throwing to improve student motivation. She concluded that improving student motivation in PAI by using snowball throwing is a useful and exciting way that can be applied in any classroom. In 2009, Dodi Irawan also studied the effect of using snowball throwing to improve student achievement in SAINS in the 4th grade of elementary school 013 Koto Tuo. ${ }^{1}$

Based on previous related studies above, the writer concluded that English teachers need an appropriate way of teaching to improve student reading comprehension. Teachers should understand what the best strategy or technique can help students understand the reading. Teachers should also know about good material that can make students interested and read quickly. It can also increase student knowledge after classroom study. In this study, the writer used a snowball throwing technique to improve student reading comprehension. The snowball throwing technique trains students to receive narrative text messages from other students and deliver the message to their group friends. A question paper contains questions made to the other students in a snowball paper. Students receiving open paper ball answer the question. Implementing this technique can be beneficial for all students to improve their class reading comprehension because they have the same opportunity to participate actively in English reading.

\section{METHODS}

\section{Research Design}

This research applied research into classroom action. It aims to find out if using snowball throwing to improve student reading to SMPN 8 Palopo 's second year. In the second year of SMPN 8 Palopo, a student class collaborated with the class's English teacher. Because the researcher is the teacher, the teacher will be the supervisor at the learning process while the writer will teach the researcher method to the students. Implementing learning to improve reading; the research was conducted in from cycle: planning, acting, observing, and reflecting.

\section{The Place and Time of the Research}

This research was conducted in the academic year 2019 at second-year students at SMPN 8 Palopo, which consists of 20 students

\section{Research subject}

This research would apply classroom action research. It aims to find out the effectiveness of using snowball throwing in the second - year students of SMPN 8 Palopo, in collaboration with the English teacher in charge, Asrika Achmad S.Pd. Because the researcher will be a teacher, the teacher was a supervisor at the learning process while the researcher taught the students the method and media of the researcher.

\section{Technique and instruments of Collecting Data}

1. Techniques

\footnotetext{
${ }^{1}$ Dodi Irawan, the Effect of Using Snowball Throwing to Improve Students achievement in SAINS at the Forth Grade of Elementary School 013 Koto Tuo (University of Sultan Syarif Kasim Riau:2009)
} 
The collecting data techniques in this classroom action are:

a. Test

The test was used to determine the students ' narrative text scores. The text itself contains narrative text in which the narrative text questions each contain five questions that will be given to each student; then, the student answers the questions given (sura and baya, lion, and mouse).

b. Interview

The interview was used to find out the level of success in implementing the use of snowball throwing in teaching reading.

2. Instruments

The instruments used in collecting data in this classroom action research were:

a. Observation List: observe student participation during the use of snowball Throwing in teaching reading. Also, as the primary instrument in the teacher-collaborator discussion part as a way to reflect in each cycle.

b. Questionnaire: to find out students whether this technique can be applied in teaching in using snowball techniques in reading

c. Camera: The researcher takes students' picture in the learning process

\section{Procedures of Collection Data} Cycle I

The researcher gave two meetings for each cycle

1. Planning

a. Analyzing the curriculum, especially the basic competence after doing the need analysis of the second year of SMPN 8 Palopo.

b. The researcher making a lesson plan about the use of snowball throwing in teaching reading comprehension on the narrative text.

c. Preparing the narrative text

2. Acting

a. The researcher introduced himself and collaborator to the students.

b. The researcher explained the aims of the learning process.

c. The researcher explained the definition and structure of a narrative text.

d. The researcher gave examples of narrative text ("Sura and Baya").

e. The researcher divided the students into two big groups.

f. Each student was given a sheet of paperwork and wrote down questions about the matter which has been described by the teacher, and then squeezing the paper became a ball shape.

g. the researcher made a conclusion

3. Observation

Some important things had been observed, those were:

a. The researcher identified and make a note about all the problems that the teacher gets when teaching and learning process.

b. The researcher did the evaluations which use the result of the study to know how far the students have improved.

c. The researcher gave the students the chance to give suggestions in action research. Reflection

This classroom action research was a success if some of the following requirements are fulfilled: 
a. Most of the students have good participation during acting (70\%).

b. Most of the students have a good score in evaluation (75\%).

\section{The technique of Data Analysis}

The data which were collected through observation in each cycle were analyzed descriptively by using percentage technique.

1. $\quad$ core $=\frac{\text { Total correct answer }}{\text { score } \text { maximum }} \times 100$

Classifying the students' scores based on the following classification:
a. Very good = $81-100 \quad$ is classified as very good
b. Good $\quad=\quad 61-80 \quad$ is classified as good
c. Fair = $41-60 \quad$ is classified as fairly
d. Poor $\quad=\quad 21-40 \quad$ is classified as poor
e. Very Poor = 1-20 is classified as very poor

Calculating the mean score of the students' reading test by using the following formula:

Where:

$$
X=\frac{\sum x}{N}
$$

$\mathrm{X}=$ the mean score

$\sum \mathrm{x}=$ the total raw score

$\mathrm{N}=$ the number of students ${ }^{2}$

2. Activities of students during the learning process analyzed by considering the students' participation and classified into very active, active, less active, and not active classification.

3. Implementation of learning by using snowball throwing in teaching reading could be categorized as; very good, good, fair, poor, and very poor classification.

4. The result of the interview

From the interview with the English teacher, the researcher obtains information using this technique for reading comprehension in the classroom and is interested in this technique in reading class using this technique to arouse the ability of the students to read about the text. The big obstacle in teaching reading, depending on his point of view, was a lack of vocabulary. The teacher asked the students to read daily, make notes about the difficult words, and use the dictionary as often as possible. The trainer also clarified that when implementing the Snowball throwing method, few restrictions were too little time to do those jobs for English subjects. Whereas, the number of students in one class is too many (20 students) to be loud and crowded. The teacher also explained that most students like about this technique the learning process is interesting, fun and, on the other hand, they are happy to say that the narrative text has new words for students to make them confused about the meaning of words in the text and through this technique most students can share their knowledge and be more active when reading material

Table 1. Reading Assessment based on Brown, H. Douglas

\footnotetext{
${ }^{2}$ Mangkuatmodjo, Pengantar Statistik, (cet.1, Jakarta: Rineka Cipta 2003), p. 58
} 


\begin{tabular}{|c|c|c|c|}
\hline & Poor 0,5 pts & Fair 1 pts & Good 2 pts \\
\hline Main Idea & $\begin{array}{l}\text { Fails to identify the } \\
\text { main idea }\end{array}$ & $\begin{array}{l}\text { Identifies the main } \\
\text { idea but cannot } \\
\text { identify supporting } \\
\text { details }\end{array}$ & $\begin{array}{l}\text { Identifies the main idea } \\
\text { as well as supporting } \\
\text { details }\end{array}$ \\
\hline Content & $\begin{array}{l}\text { Fails to identify the } \\
\text { content of the story }\end{array}$ & $\begin{array}{l}\text { Identifies the content } \\
\text { but cannot identifying } \\
\text { independently the } \\
\text { content }\end{array}$ & $\begin{array}{l}\text { Can identify the content } \\
\text { when reading }\end{array}$ \\
\hline Vocabulary & $\begin{array}{l}\text { Decodes an } \\
\text { unfamiliar word, } \\
\text { but does not } \\
\text { interpret the } \\
\text { meaning } \\
\text { independently }\end{array}$ & $\begin{array}{l}\text { Decodes the } \\
\text { unfamiliar word but is } \\
\text { not always able to } \\
\text { interpret the meaning } \\
\text { from context }\end{array}$ & $\begin{array}{l}\text { Interpret the meanings } \\
\text { of unfamiliar words }\end{array}$ \\
\hline Inference & $\begin{array}{l}\text { Can not conclude } \\
\text { the inferred } \\
\text { message or suggest }\end{array}$ & $\begin{array}{l}\text { Identifies or } \\
\text { acknowledges, but } \\
\text { misinterprets the } \\
\text { inference }\end{array}$ & $\begin{array}{l}\text { Can identify when } \\
\text { massage is inferred and } \\
\text { can conclude the } \\
\text { accurate meaning }\end{array}$ \\
\hline Expression & $\begin{array}{l}\text { Cannot identify } \\
\text { expression in the } \\
\text { story }\end{array}$ & $\begin{array}{l}\text { Identifies expression, } \\
\text { but cannot } \\
\text { independently }\end{array}$ & $\begin{array}{l}\text { Identify the expression } \\
\text { when reading the text }\end{array}$ \\
\hline
\end{tabular}

\section{RESULTS}

The findings of the research explained the cycles of the teaching and learning process of this current research. In this case, there were two cycles and two meetings for each cycle.

Cycle I

The first cycle of this classroom action research consists of planning, acting, observing, and reflecting

\section{Planning}

a. Analyzing the curriculum, especially the basic competence after doing the need analysis of the second-year students of SMPN 8 Palopo.

b. Making a lesson plan about the use of snowball throwing in teaching reading on narrative text

c. Preparing the narrative text (reading material)

d. Divide the students into a group

e. Preparing the instrument which is used in the cycle of classroom action research Acting

Cycle 1 action started on September 23 , 2019, 10:20 a.m. First lesson. That is the introduction and connection. The authors discussed and studied the introduction. In this case, first, the researcher gave instructions to prepare physically or psychologically by expressing greeting and introduced himself and her co-worker, then prayed together for the beginning lesson. Calling the roll, refreshing their focus, such as checking students ' attendance and encouraging them to join the learning process, explaining the narrative 
text, and throwing a snowball at the second meeting. The student then divided the students into two big groups and then decided each group's leader. The researcher gave questions for each group leader, then returned to their group and distributed the question to each group member. The grouping at this cycle one just randomly, like as; group A they were; R003, R005, R008, R009, R002, R013, R015, R018, R016, R020 group B they were; R001, R004, R006, R007, R010, R011, R012, R014, R017, R019. Further, the researcher explained the purpose of the learning process and also the basic competence that would be achieved. Third, the researcher delivered the scope of the learning material and gave a little bit explanation about the title of research that would be studied.

The researcher asked the students, studied the narrative text by throwing snowball? Some students replied they had ever learned the narrative text, but they did not use snowball throwing. The researcher then explained what snowball throwing was, and its steps in teaching and learning comprehension of reading, what they had to do during the class. The researcher then explained the narrative text, social function, characteristic, generic structure, and many more. After explaining, the researcher gave students the narrative text. The researcher gave all students "Sura and Baya" text. Each student was given sheet paperwork, and each student wrote down questions based on the researcher's reading topic, then they squeezed the paper into a ball shape, and then the researcher gave the command to throw the question ball from one student to another. After the students got a ball or a question, they had the opportunity to answer the question written in the ball-shaped paper, group ' A' threw the ball question to group ' B' Next; the students had to keep throwing the paper ball to another student when the student could not answer the question that was related to the reading topic and the paper ball would be out. If all students could not answer correctly, the researcher could give the right answer. Last, the teacher gave morality suggestions to the students and gave appreciated, and the teacher said thanks to students who participated in her research. Moreover, the last, the researcher closed the teaching-learning process by saying "Hamdalah" and prayer together.

\section{Observing}

During the implementation of the teaching-learning process, the researcher and collaborator made observations using snowball throwing in the first cycle. They found that some students had improved reading comprehension. Students said the learning process was interesting, enjoyable, and happy. On the other hand, the researcher also found some others still below target or criteria. Such as; the students did not know the learning by using snowball throwing the class was still noisy because the students were still busy with their activity. The narrative text had some new words to confuse the meaning of the words in the text. The learning process was not active. Evaluation of student reading comprehension showed that student reading comprehension mastery was mostly in low scores. Evaluation of students ' reading understanding test showed that some students had low scores and the mean score was 56

Table 2. Score of the students reading in cycle 1

\begin{tabular}{ccc}
\hline No & Respondents & Score \\
\hline 1 & R1 & 60
\end{tabular}




\begin{tabular}{ccc}
2 & R2 & 60 \\
3 & R3 & 55 \\
4 & R4 & 45 \\
5 & R5 & 70 \\
6 & R6 & 45 \\
7 & R7 & 70 \\
8 & R8 & 55 \\
9 & R9 & 60 \\
10 & R10 & 55 \\
11 & R11 & 60 \\
12 & R12 & 35 \\
13 & R13 & 75 \\
14 & R14 & 50 \\
15 & R15 & 35 \\
16 & R16 & 80 \\
17 & R17 & 55 \\
18 & R18 & 40 \\
19 & R19 & 60 \\
20 & R20 & 55 \\
\hline
\end{tabular}

Calculating the mean of the students' reading test of cycle 1

$$
\begin{aligned}
X & =\frac{\sum \mathrm{x}}{N} \\
= & \frac{1120}{20} \\
& =56
\end{aligned}
$$

The table explains that a higher score is 80 , and the lowest score is 35 . There is one student who got a score of 80 , there is one student who got a score of 75 , there are two students who got a score of 70 , there are five students who got a score of 60 , there are five students who got a score of 55 , there is one student who got a score of 50 , there are two students who got score 45 , there is one student who got a score of 40 , and there are two students who got a score of 35 .

Table 3. The rating percentage of students' in cycle 1

\begin{tabular}{lccc}
\hline \multicolumn{1}{c}{ Classification } & Score & Frequency & Percentage \\
\hline Very good & $81-100$ & - & - \\
Good & $61-80$ & 4 & $20 \%$ \\
Fair & $41-60$ & 11 & $55 \%$ \\
Poor & $21-40$ & 5 & $25 \%$ \\
Very poor & $1-20$ & - & - \\
\hline
\end{tabular}


The table above shows the students' score in the test of cycle 1 , there was none student got 'very good,' 4 (20\%) students got 'good,' 11 (55\%) students got 'fair,' 5 (25\%) students got 'poor,' and none student got 'very poor' classification

Figure 1. Diagram Result of the Test in Cycle 1

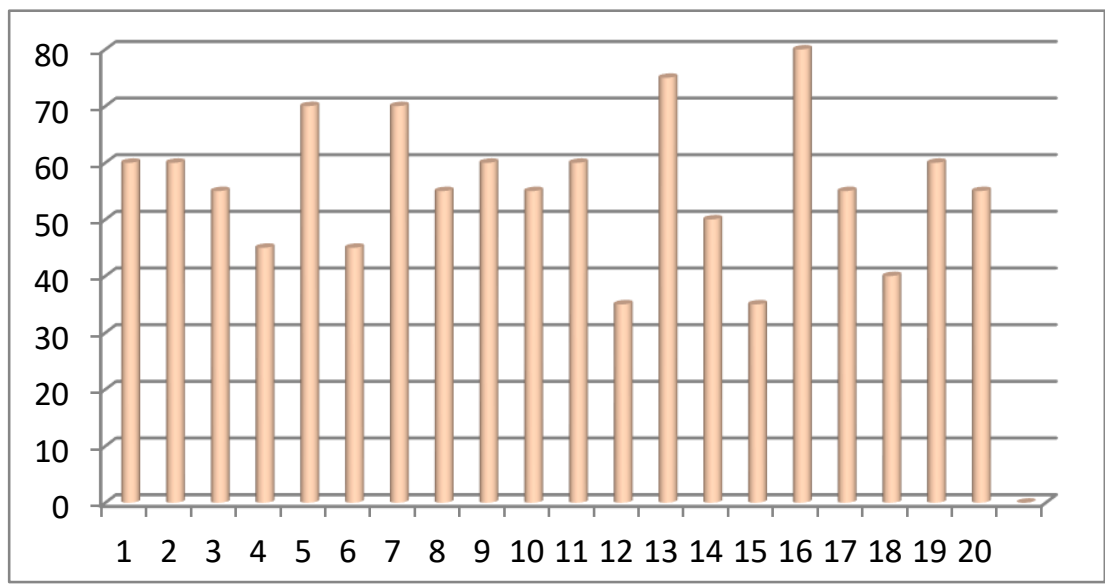

After that, the researcher made observations on class students ' activities. The researcher did it with the observer, and she got some data on the learning process's student activities. Based on the observation result, she got some data, like two students were not active, six students were less active, nine students were active, and three students were very active. The table below shows it.

Table 4 The observation of the students' activity in cycle 1

\begin{tabular}{lccccc}
\hline No & Respondents & Not Active & Less Active & Active & Very Active \\
\hline 1 & R1 & & $\sqrt{ }$ & $\sqrt{ }$ \\
2 & R2 & & $\sqrt{ }$ & \\
3 & R3 & & $\sqrt{ }$ & $\sqrt{ }$ & \\
4 & R4 & & $\sqrt{ }$ & \\
5 & R5 & & & $\sqrt{ }$ & \\
6 & R6 & & $\sqrt{ }$ & \\
7 & R7 & & & $\sqrt{ }$ & \\
8 & R8 & & & & \\
9 & R9 & & & $\sqrt{ }$ & \\
10 & R10 & & & & \\
11 & R11 & & & & \\
12 & R12 & & & \\
13 & R13 & & & \\
14 & R14 & & $\sqrt{ }$ & \\
15 & R15 & & & & \\
16 & R16 & & & & \\
17 & R17 & & $\sqrt{ }$ & \\
18 & R18 & & 6 & 9 & \\
19 & R19 & & & & \\
20 & R20 & & & & \\
\hline
\end{tabular}


Where:

1. Very active: the students are responsive and participated fully in all activities in the learning and teaching process.

2. Active: the students' response to the material and interacting with others, whether to the teacher or his/her friends.

3. Less active: the students pay attention and give responses once in a while.

4. Not active: the students do not give a response to the material; she/he looks confused, bored and sometimes leaves the class, sleepy, fiddling mobile, write or something beyond the material, and many more.

Table 5. The percentage of students' active participation in cycle 1

\begin{tabular}{llll}
\hline \multicolumn{1}{c}{ Classification } & \multicolumn{1}{c}{ Frequency } & Percentage (\%) \\
\hline Not Active & 2 & & $10 \%$ \\
Less Active & 6 & & $30 \%$ \\
Active & 9 & $45 \%$ \\
Very Active & 3 & $15 \%$ & \\
\hline
\end{tabular}

Where:

$$
P=\frac{F}{N} \times 100
$$

P: Percentage

F: Frequency

$\mathrm{N}$ : Total of students. (Oktavianti, 2016)

Figure 2. Diagram the Students' Participation

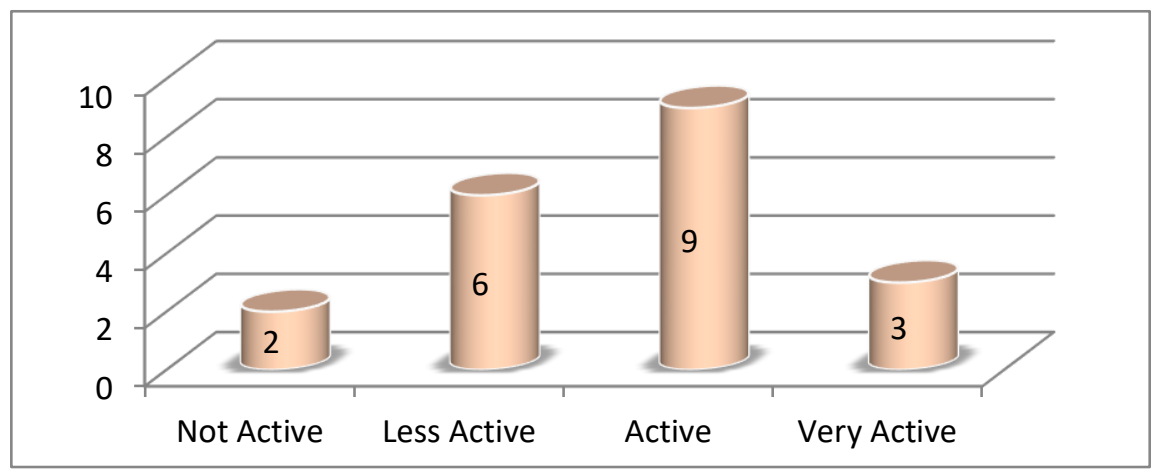

Based on the research data in cycle two shown by the above description that included 20 students, when the learning process was running, there were two students not active in reading class and percentage reached (10\%). The less active students were 6 , reaching a percentage (30\%). The active students were nine and reached a percentage $(45 \%)$, three very active students, and a percentage (15\%). This section was not a success because the researcher and collaborator still found a weakness.

\section{Reflecting}

At this stage, the researcher had significant weakness in teaching reading comprehension in implementing or using snowball throwing in cycle I and then continued cycling 2 . The class was still noisy because the students were still busy with 
their activity and they were bothering each other. Most of the students were still confused about narrative text through Snowball Throwing. They were still confused with the rules of this activity even though the researcher had explained. The narrative text had some new words for students, so that could make them confused about the meaning of the words in the text. It made the learning process was not active. Based on the weaknesses above, it proved that this cycle 1 failed or far from the target. So, it would continue in the cycle 2 . For solving the problem or weakness in cycle 1 , the researcher was planned in cycle two as follows:

a. The researcher who acts the teacher use glossaries in the narrative text to support the student in reading comprehension of the narrative text. It would make the learning process more effective, and the students focus more on reading narrative text.

b. The teacher gave more motivation and game before beginning the learning process.

c. The teacher was setting the classroom into four groups to create the learning process better.

d. The teacher gave more explanation about the material.

\section{Cycle II}

After doing observation and reflecting in the first cycle, there was still a weakness in the first cycle. Then there are two meetings in this cycle to decrease the weaknesses and create success in the second cycle, so the second cycle was done. Based on the following preparation:

Planning

The planning in the second cycle as follows:

a. The researcher who acts the teacher made a lesson plan about the use of snowball throwing in teaching reading comprehension on the narrative text.

b. Before starting the learning process, the teacher encouraged the students by giving motivation and positive suggestions to the students in order to be more active in the learning process.

c. The teacher has to give the game before beginning the learning process.

d. The teacher gave more explanation about the material.

e. The teacher gave glossaries in the narrative text to support the students in reading comprehension of the narrative text.

f. The teacher was setting the classroom into four groups to create the learning process better.

\section{Acting}

The second cycle continued on October 2 at 10:45 a.m. The first meeting started like a previous meeting. By greeting the students like saying hi or hello, the researcher opened the class and asked their condition by saying, "how are you?" and then prayed together for the lesson. After the researcher gave the game before the material began, the researcher reviewed the material given before. Next, the researcher gave more explanation in understanding narrative text well and efficiently and gave more guidance to them on how to understand it well and smoothly. In the second meeting, the researcher explained the material about narrative text and snowballed throwing. After that, the researcher divided the students into four groups. Each group consisted of five students. The researcher was grouping or combining the students base on the list of students' names. Group 1, that was; R.001, R.002, R003, R004, R.005, group 2, they were: R.006, 
R.007, R.008, R.009, R.010, group 3, they were: R.011, R.012, R.013, R.014, R.015, and last group, they were R.016, R.017, R.018, R.019, R. 020.

After that, called each group leader came forward to explain the matter. Then the researcher gave each group leader some questions and told the member about the teacher's explanation. The researcher gave a text about "The lion and the Mouse" to all groups. Each student was given a sheet of paperwork, and every student wrote down a question about the reading topic which described by the researcher, then they squeezing the paper become a ball shape, and then the researcher gave the command to throw the question ball from one student to another student group. At cycle two the group 1 threw to group 2, group 2 threw to group 3, group 3 threw to group 4, and group 4 threw to group 1. It showed until three times for $+/-15$ minutes. After the students got one ball or one question, then they had the opportunity to answer questions related to the topic that is written in the ball-shaped paper taking turns. Next, the students must continue to throw the paper ball to another group when the member could not answer the question related to the reading topic and the paper ball would be thrown continuously until the member could answer correctly if all the students could not answer correctly so that the researcher could give the correct answer in the last learning conclusion. The researcher asked the students to memorize some vocabulary in the next meeting. After that, the teacher gave some positive suggestions to the students again, such as encouraging, motivating, and giving them spirit more and more before ending the meeting.

\section{Observing}

The condition of the class in the second cycle was different from the first cycle. In this case, most of the students got better and became more be exiting. The students looked enjoyed in learning narrative text through snowball throwing. They were more active in class during the group learning process, though some students were still crowded. The grouping of the students was just based on the list of students' names, and they were at the same level so that they just were bothering each other. The narrative text had some new words for students, so that could make them confused about the meaning of the words in the text. The narrative reading only was given one for each group. It made the learning process was less active. Although they still could be focused on the learning process when they practiced within their group, they proof the scores of the students were increased. The students' participation in learning narrative text through snowball throwing was more enjoyable and better because most of the students had practiced in asking, answer, responding to some questions that the researcher given and the text had some glossaries. The evaluation of students' understanding in learning narrative text through snowball throwing showed that in this cycle. The students got a better score than in the first cycle. The resulting score of students' presented was increased than in the first cycle because the students more are active, more be accuracy, and fluency in presented their answer. Therefore almost all of them Followed the learning process enthusiastically so that the class seemed more active than before. Evaluation of the student's reading comprehension showed that students' master in reading was high scores. The mean score was 82,75 .

Table 6. Score of the students' reading in cycle 2

No. Respondents Score




\begin{tabular}{lrc}
\hline 1. & R1 & 90 \\
2. & R2 & 90 \\
3. & R3 & 95 \\
4. & R4 & 80 \\
5. & R5 & 80 \\
6. & R6 & 80 \\
7. & R7 & 90 \\
8. & R8 & 80 \\
9. & R9 & 90 \\
10. & R10 & 80 \\
11. & R11 & 75 \\
12. & R12 & 75 \\
13. & R13 & 95 \\
14. & R14 & 80 \\
15. & R15 & 80 \\
16. & R16 & 90 \\
17. & R17 & 75 \\
18. & R18 & 75 \\
19. & R19 & 80 \\
20. & R20 & 75 \\
\hline
\end{tabular}

The mean score of the students' reading test of the cycle:

$$
\begin{array}{rlr}
X=\frac{\Sigma \mathrm{x}}{N} & =82,75 & =\frac{1655}{20}
\end{array}
$$

The table explains that a higher score is 95 , and the lowest is score is 75.2 students got a score of 95,5 students got a score of 90 , eight students got to score 80 , five students got a score of 75 .

Table 7. The rating percentage of students' score in cycle 2

\begin{tabular}{lccc}
\hline \multicolumn{1}{c}{ Classification } & Score & Frequency & Percentage \\
\hline Very Good & $81-100$ & 7 & $35 \%$ \\
Good & $61-80$ & 13 & $65 \%$ \\
Fair & $41-60$ & - & - \\
Poor & $21-40$ & - & - \\
Very Poor & $1-20$ & - & - \\
\hline
\end{tabular}

The table above shows that the students' score in the test of cycle 2, there was student got 'very good,' 7 (35\%) students got 'good,' 13 (65\%) none students got 'fair,' got 'poor' and none student got 'very poor' classification.

Figure 3. Diagram Result of the Test in Cycle 2

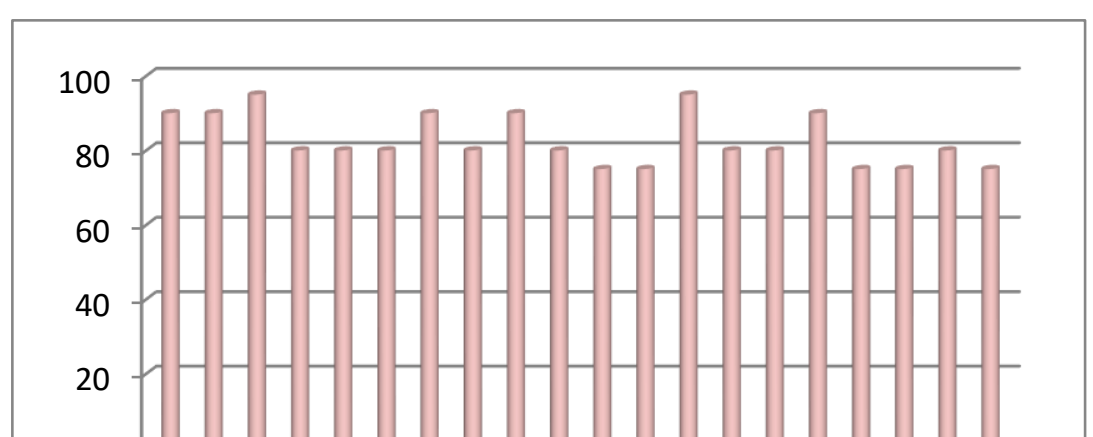


After that, the researcher did observations about the activities of students in the class. The researcher did it with the observer, and she got some data about the activities of students in the learning process. Based on the result of observation, she got some data, such as five students were less active none student was not active.

Table 8. The observation of the students' activity in cycle 2

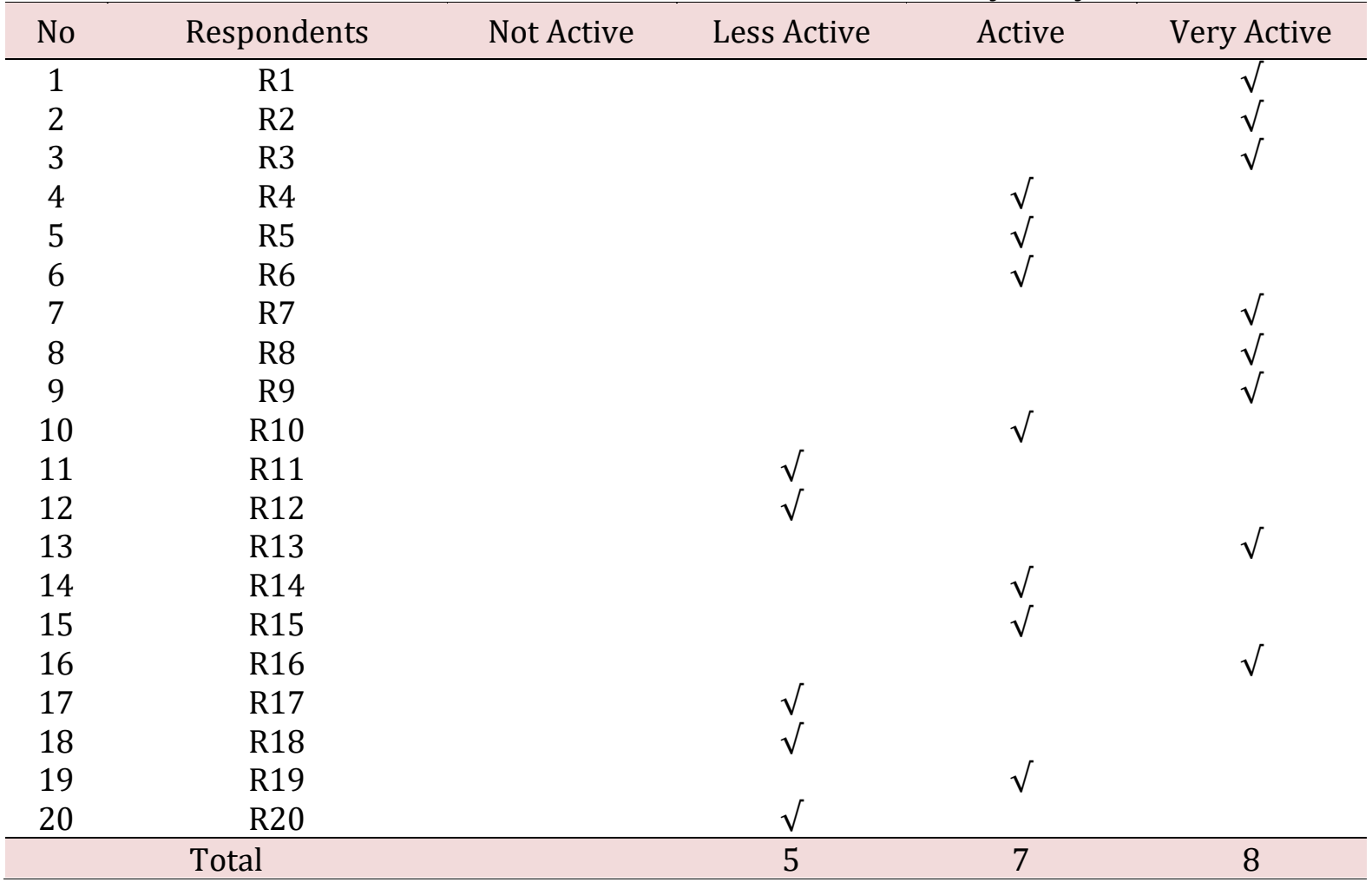

Where:

1. Very active: the students are responsive and participated fully in all activities in the learning and teaching process.

2. Active: the students' response to the material and interacting with others, whether to the teacher or his/ her friends.

3. Less active: the students pay attention and give responses once in a while.

4. Not active: the students do not give the response to the material; she/he looks confused, bored and sometimes leaves the class, sleepy, fiddling mobile, write or something beyond of the material, and many more.

Figure 4. Diagram the Students' Participation in cycle 2 


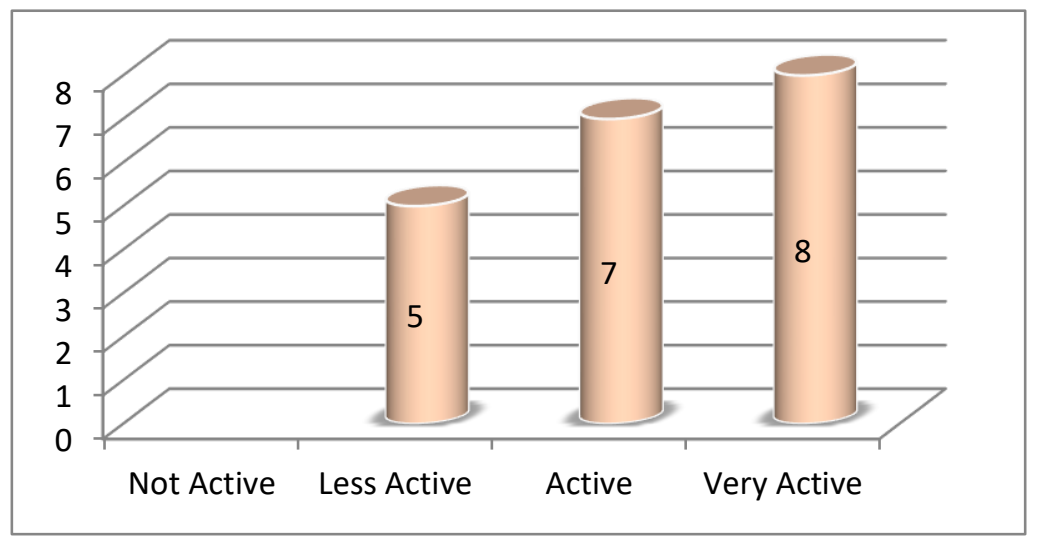

Table 4.12

The percentage of students' active participation in cycle 2

\begin{tabular}{llll}
\hline \multicolumn{1}{c}{ Classification } & \multicolumn{1}{c}{ Frequency } & Percentage \\
\hline Very Active & 8 & & $40 \%$ \\
Active & 7 & $35 \%$ & \\
Less active & 5 & & $25 \%$ \\
Not active & - & - & \\
\hline
\end{tabular}

Where:

$$
P=\frac{F}{N} \times 100
$$

P: Percentage

F: Frequency

N: Total of students. ${ }^{3}$

Based on the data in cycle two shown in the above description, which included 20 students, there were 5 when the learning process was running, and the percentage was $25 \%$. The active students were 7 , and the percentage reached $35 \%$. The very active students were 8 , and the percentage reached $40 \%$.

\section{Reflection}

Some strong point in cycle 2 , as follows:

a. Most of the students were more active during the learning process, and they were real enthusiasm to read the text. It happened because all of the students took one narrative text and made the learning process more effective, and the students more focus on reading narrative text.

b. Most of the students were easier to comprehend the narrative text. It happened because in each narrative text there were glossaries and memorizing some vocabularies so that it could support the students in comprehension the narrative text

c. Most of the students, even very active in reading text when the learning process was running, 7 were active, and eight were very active, were active in learning processes such as, are responsive and fully involved in all activities in the learning and teaching process, and were active in answering questions, less active since they did not comment or respond to the questions

\footnotetext{
${ }^{3}$ Ibid. p.73
} 
d. The grouping of the students was based on the students' level. It would make them more active and focus on learning. They were not bothering each other, so the atmosphere of the class was conducive.

e. The applying of snowball throwing is more attractive to students in improving reading comprehension

f. It is giving students more chances to share their knowledge in the teaching and learning process. It could give students more confidence in the teaching and learning process.

g. The ideal mean score has achieved, in the first cycle was 56 , and then in the second cycle was become 82,75

\section{DISCUSSION}

By considering the findings, the researcher presents the discussion of data given to the students, the section described on the efficacy of snowball throwing method in teaching reading comprehension, especially on the narrative text at SMPN 8 Palopo's Second - year students. The students ' score at SMPN 8 Palopo 's second-year students was ineffective in the first cycle, then in the second cycle. When using snowball throwing, learning can identify results cycles 1 and 2 . To find out the effectiveness of the snowball throwing method on teaching reading comprehension on the narrative text on this case, the researcher discusses data analysis results according to the scope of the research. The discussion aims to know the effectiveness of the snowball throwing method in teaching second-year SMPN8 Palopo students reading narrative text.

\section{Cycle 1}

Based on the student test analysis in cycle I, the mean first-period value is 56 . The average score of the students in this research was 75. It showed that cycle still far from the goal. Only three students, very active in the learning process, were responsive and participated fully in all learning process activities. Only nine students active in the teaching process were material responses and interacting with the teacher or his friends. There were six less active students and two non-active students, because they were only once, even gave answers about the material they did not respond. It means that only $45 \%$ and $10 \%$ of students were not active in class. From data and observation, the researcher found that three students were very active and nine were active during the learning process, which caused them to like the way the researcher taught them by using snowball throwing that they could enjoy and have fun with their friends, and also the students felt happy to receive and understand the lesson.

Furthermore, the researcher also found class problems, why students were not active and less active because the students were not familiar with the learning by using snowball throwing, did not dare to be active during the learning process, the class was still noisy because the students were still busy with their activity. The narrative text had some new words for students, making them confused about the meaning of narrative text words. Additionally, students have less language. It made students less active in reading narrative text. Evaluation of the students reading comprehension showed that students' mastery of reading comprehension was mostly in low scores. The mean score was only 56 , and this still far from the goal. The rating percentage of students' score in reading test of cycle 1, there was none student got 'very good,' 4 (20\%) students got 'good,' 11(55\%) students got 'fair,' 5 (25\%) students got 'poor,' and none student got 'very poor' 
classification. The researcher also realized that teaching had some weaknesses, as the researcher sat in the chair explaining the material to her unclear and weak. It means that in cycle one, the researcher was not successful in teaching reading comprehension on the narrative text by the snowball Throwing method. Before the researcher continued to the next cycle, she planned to repair some of the aspects that make the goal can be not achieved, like the weakness in teaching. Therefore, the researcher had to continue to cycle 2.

\section{Cycle 2}

In the second cycle revised from the first cycle, we made a new plan in order to solve the problems in cycle 1 . The researcher repaired the weakness in implementationSnowball Throwing in teaching reading comprehension in cycle 1 . The teacher planned some solutions for the next cycle to solve problems like before starting the learning process, and the researcher encouraged the students through motivation. Before starting the learning process, the teacher gives games, giving more explanation about the material, giving glossaries in the narrative text to help students understand the narrative text and setting the classroom in groups to create learning process better.

By doing the procedures above, the researcher found that students' participation was good; they did not look bored. The students looked enjoyed in learning narrative text through snowball throwing. There was a development from the students on reading narrative text, and the teaching material seemed more interesting for the students in cycle 2 . The students' participation in learning narrative text through snowball throwing was more enjoyable and better because most of the students had practiced in asking, answer, responding to some questions that the researcher given and the text had some glossaries.

Meanwhile, the percentage of students' participation in cycle 2 was still varieties too. Which five students were less active in reading class when learning, the process was running, and the percentage reached $5(25 \%)$. The active students were 7 , and the percentage reached (35\%). Very active students were 8, and percentage reached $(40 \%)$. Referred to the result of data analysis, the researcher found that the students' active participation was better than the result in cycle 1 . The researcher found in cycle two had been improved as the accumulation from the percentage of very active was $40 \%$, and active was $35 \%$, and less active reached $25 \%$

However, The average score that students got in the first cycle had not reached the criteria of success in the working indicator. The problem in the first cycle motivated the teacher to students more intense. It made new plans such as rearrange the student's position in the group, giving more explanation about the material, giving the narrative reading to all students, encouraging the students to memorize vocabulary, besides, by giving more chances to the students to got the good score to share their knowledge in teaching and learning process. The researcher encouraged the students by giving motivation, gave the game before beginning the learning process, gave more explanation about the material, gave the narrative reading to all students. The grouping of the students was based on students' level randomly; it would make them more active and focus on learning, encouraging the students to memorize vocabulary, giving more chance to the students who got a good score to share their knowledge in teaching and learning process. It could give a chance for students to be more confident in the teaching and 
learning process. The researcher gave a reward to the winner. It was stimulated their interest in learning.

By doing the procedures above, the researcher found that students' participation was very good; they did not look bored. The teaching material seemed interesting for the students. There was a development from the students on reading narrative text in cycle 2 , and the condition of the class can be controlled. The students easier comprehend the text and more active in the leaning process. They were enthusiastic about the learning process.

Meanwhile, the percentage of students' participation in cycle 2, there was none student not active, there were five students were less active in reading class when the learning process was running, and percentage reached $25 \%$. The active students were 7 , and the percentage reached 35\%. The very active students were 8 , and the percentage reached $40 \%$. Referred to the result of data analysis, the researcher found that the students' active participation was better than the result in cycle 1 . The researcher also found that the success criteria in cycle two were achieved by accumulating the percentage of very active and active.

The mean score of the students' test in cycle 1 was 56 ; after continued to cycle, the mean score of the students' test had improved 82,75 , The rating percentage of students' score in reading test of cycle 2 . It means that there were significant changes score from cycle 1 , till cycle 2 . In cycle 2 , the students easier comprehend the text and more active in the teaching-learning process. Also, the goal of the research can be achieved. The teacher gave more motivation to study. Based on the observation activities, this cycle during the learning process by snowball throwing was very effective because most of the students' interest in the learning process. They are more enjoyable and more spirit in their activity, especially in their group, the class conditions were more conducive, and the students were friendly with friends.

Based on the result above, the teacher finished the dominant learning process, they had a level of achievement, and the researcher has known that teaching reading comprehension through the snowball throwing method was appropriate in teaching reading comprehension, especially for reading narrative text. They concluded that using the snowball throwing model is effective in teaching reading comprehension the research findings that the significant improvement of students' reading comprehension. Through snowball throwing, the students showed great interest in being active in the teachinglearning process. In the classroom, they were eager to join all activities. Through snowball throwing, the students did not only can learn the material but also could learn more cooperative to other students.

By considering the condition in cycle 1 , and cycle 2, this research proposed some procedures in using the snowball throwing method in teaching reading comprehension, as follows:

a. The teacher was encouraging the students by giving motivation.

b. The teacher was giving games before beginning the learning process, giving more explanation about the material.

c. The teacher is giving glossaries in the narrative text to support the students in reading comprehension of the narrative text.

d. The teacher is giving the narrative reading to all students.

e. The grouping of the students was based on students' level randomly; it would make them more active and focus on learning. 
f. The teacher was encouraging the students to memorize vocabulary.

g. The teacher is giving a chance to the students who got good scores to share their knowledge in the teaching and learning process. It could give a chance for students to be more confident in the teaching and learning process.

\section{CONCLUSION}

After finishing the research, the researcher concludes that the snowball throwing in teaching reading comprehension to the second-year students of SMPN 8 Palopo snowball throwing could be conducted in cycle 2, as follows:

a. Forming the students into a small group that consisted of 5 students, the grouping of the students was based on students' level randomly, it made them more active and focused on learning

b. Giving narrative text to all students it would make the learning process more effective, and the students focus more on reading narrative text.

c. Giving glossaries in each text.it helped the students easier to comprehend the narrative text

d. Giving reward/gift for appreciating the winner

e. Giving more motivation to the students that working to gather is easier to comprehend the reading text

f. Reading comprehension of the students can be seen from the result of the mean score has increased from cycle $1(56)$ to cycle $2(82,75)$. So, Teaching reading comprehension through snowball throwing can be implemented in reading material, especially narrative text

\section{REFERENCES}

Artono Wardiman, English In Focus For Grade VII Junior High School,P.102

Agus Suprijono, Cooperative Learning Teori: dan Aplikasi PAIKEM, (Yogyakarta :Pustaka Pelajar,2013), p. 128.

Cristian Nuttal,Teaching Reading Skill in Foreign Language,(London, Crisstianuttal,1982),P.33

Cicik Kurniawati, BahasaInggris Program lmu Pengetahan Alam dan ilmu Pengetahuan Sosial untuk SMA/MA, (Surabaya; IntanPariwara, 2011), p 92-93

Dodi Irawan, the Effect of Using Snowball Throwing to Improve Students achievement in SAINS at the Forth Grade of Elementary School 013 Koto Tuo (University of Sultan Syarif Kasim Riau:2009)

David and Roger Johnson,Cooperative Learning,2011,0nline http:/wwwclcrc. com/pages/cl.html.Accessed on may,20th 2019

David Cristal,A Dictionary of Linguistics and Phonetics,(New York: Basil Blackwell Lid:1985).p.63

Dick King Smith.http://englishonline.tki.org.nz/English-Online/Teacher-needs/Review ed- resources/Reading/ Features-of-text-forms/Narrative.Accessed on may,18 ${ }^{\text {th }}$ 2019 
Dean satriawan.http://deansatriawan.wordpress.comsnowball-throwing-teachingtechnique/. Accessed on may,20th 2019

Fransoise Grallet, Developing Reading,(London:Cambridge: 1981).

Geoffrey Broughton,etal," Teaching English as a foreign Language",(London,1985), p.90.

H.DouglasBrown,Principle of Language Learning and Teaching, (fourth Edition;NewJersey:prentice hall international Limitid,1987),p.7.

IGAK Wardhani, et al., PenelitianTindakanKelas, (Cet. 11; Jakarta: Universitas Terbuka, 2010), p.1.4

Iksan, M. (n.d.). A SURVEY OF STUDENTS'LANGUAGE LEARNING STRATEGIES AND THEIR ENGLISH LEARNING ACHIEVEMENT IN SMA NEGERI 1 PALOPO.

Iksan, M., \& Dirham, D. (2018). The Influence of the Economic Students' Motivations and Language Learning Strategies towards Their English Achievement in STIE Muhammadiyah Palopo. Ethical Lingua: Journal of Language Teaching and Literature, 5(1), 110-121.

Ilham, D. (2020). The Challenge of Islamic Education and How to Change. International Journal of Asian Education, 1(1), 15-20. https://doi.org/10.46966/ijae.v1i1.16

IraPane.http//junal.unimed.ac.id.2012.index.phpelluarticleviewfile.13941152.Improvin gThe Students'Speaking Achievement in Narrative Text Through Snowball Throwing Model.Accessed on may,20th 2019

Mangkuatmodjo, PengantarStatistik, (cet. 1, Jakarta: RinekaCipta 2003), p. 58

Muhammad anshari, http://www.muhammadanshari9.blogspot.com/2013/10/modelpembelajaran-snowbal-throwing.html.Accessed on may,16 ${ }^{\text {th } 2019}$

Minati," increasing the students'Reading Skill at the Second Year of SMA Negeri 1 Baebunta Through Anecdotes" (Papolo:ThesisUncokro Palopo,2009),p.30.

Markhelffels in thesis Farida Middin,The Difficulties of Students in Finding Main Idea and Supporting Detail Text in Reading Comprehension of Second Year of Students of English Department in STAIN palopo,(palopo, 2007), p.13

Oktavianti, O. (2016). Pengaruh motivasi berprestasi dan cara belajar terhadap prestasi belajar siswa SMKN 5 di Kota Batam. JURNAL DIMENSI, 2(3).

Setiawan, E. (2019). STUDI PERBANDINGAN MODEL PEMBELAJARAN SNOWBAL THROWING DENGAN PEMBELAJARAN KONVENSIONAL TERHADAP AKTIVITAS DAN HASIL BELAJAR DASAR PERANCANGAN TEKNIK MESIN (DPTM) SISWA KELAS X JURUSAN TEKNIK MESIN SMK NEGERI 1 BUKITTINGGI. Ranah Research: Journal of Multidisciplinary Research and Development, 2(1), 238-243.

Wadirman, A., Jahur, M. B., \& Djusma, M. S. (2008). English in Focus for Grade VIII Junior High School (SMP/MTs). Jakarta: Pusat Perbukuan Departemen Pendidikan Nasional. 